\title{
CURRENTS AND MIXING ON THE SILL OF AMBON BAY MEASURED WITH DROGUES
}

\author{
by \\ WALMAN ${ }^{1)}$ and JAMES JAY ANDERSON ${ }^{2)}$
}

\begin{abstract}
Currents and mixing properties on the sill of Ambon Bay were measured with drogues. Current speed of $0.62 \mathrm{~m} / \mathrm{sec}$ was observed. A mixing model suggests material released on the sill would decrease by a factor of $2 \times 10^{4}$ in one hour. Drogue construction and data reduction methods are described.
\end{abstract}

\section{ABSTRAK}

ARUS DAN SIFAT PENGADUKAN YANG DIUKUR DENGAN PARASUT DI AMBANG TELUK AMBON. Sifat arus dan pengadukan di ambang Teluk Ambon telah diamati dengan parasut. Kecepatan arus yang diperoleh $0.60 \mathrm{~m} /$ det. Dengan suatu model pengadukan, diduga suatu zat yang dapat larut yang dilepaskan di ambang akan berkurang sebesar 2 x $10^{4}$ dalam satu jam. Pembuatan parasut dan metode analisa diuraikan.

\section{INTRODUCTION}

Ambon Bay on Ambon Island in the Molucca Archipelago has an enclosed inner bay separated from a deep outer bay by a shallow sill. ANDERSON \& SAPULETTE (1981), using seasonal temperature observations concluded that the water from the outer bay replaces the inner bay bottom water during the southeast wet monsoon between February and August. WENNo \& ANDERSON (1985) observed this renewal process in August 1982 and concluded that the tidal upwelling draws outer bay thermocline water up on to the sill on the flood tide. Temperature profiles supported by a model of tidal upwelling based on the barotrophic tidal current and accompanying internal wave generated at the sill, suggest that water from the $75 \mathrm{~m}$ deep thermocline can be drawn up over the $10 \mathrm{~m}$ deep sill and into the inner bay.

We report on the use of drogues to study currents and mixing of the surface water on the sill of Ambon Bay for flood and ebb tides and estimate the rate of dispersion of a pollutant on the sill.

1) Balai Penelitian dan Pengembangan Sumberdaya Laut, Puslitbang Oseanologi, LIPI.

2) School of Fisheries, University of Washington Seattle, Washington 98195, U.S.A. 


\section{WALM AN \& J.J. ANDERSON}

\section{FIELD METHODS}

Currents were measured with surface drogues using the procedures of EBBESMEYER \& OKUBO (1974) and OKUBO \& EBBESMEYER (1976).

A drogue consists of a large drag element that moves with the current and a flag on a pole sticking out of the water that can be tracked at a distance. The drag unit has about $95 \%$ of the surface area so the drogue moves with the current and is only slightly affected by the wind. The drogue has $1.2 \times 0.9 \mathrm{~m}$ rectangles of cloth stretched on bamboo frames tied together with plastic line. The rectangle is attached to a $2.5 \mathrm{~m}$ bamboo pole with a 1-liter can filled with cement to weight one end, a float 1/3 up pole, and a coloured flag at the top. The flag sticks $1.5 \mathrm{~m}$ out of the water and drogue floats upright of $1 \mathrm{~m}$ (Fig. 1).

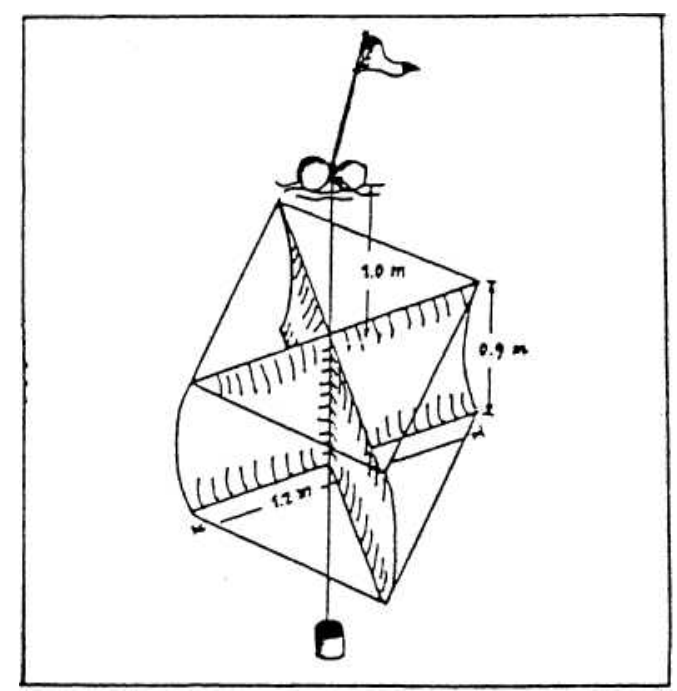

Figure 1. Size and construction of a drogue.

Five drogues were constructed, each with a different coloured flag in the shape of a triangle, $0.4 \mathrm{~m}$ length and $0.3 \mathrm{~m}$ at the base.

Drogue positions were determined by two observers on shore. The observers took fixes at $5 \mathrm{~min} \pm 1 \mathrm{~min}$ intervals with sextants measuring the angle of a drogue relative to a navigation buoy on the sill. A drogue position is determined by the intersection of the angles measured by the two observers in the same time interval. Three to four drogues can be followed up to one mile with this method. The positions of .six or more drogues can be determined over several miles by measuring the angles from a boat instead from a shore. In this case a boat is brought along side a drogue and two or more angles between three (or more) fixed land positions are measured. 


\section{CURRENTS AND MIXING ON THE SILL OF AMBON BAY}

\section{DATA ANALYSIS}

To smooth the data and obtain positions at uniform intervals of time the northsouth and east-west coordinates of the positions were fit with a polynomial equation of between a third and sixth order. The equation of order $n$ is

$$
\begin{aligned}
& x(t)=\sum_{j=0}^{n} a_{j} \mathrm{t}^{j} \text {, where } j=0 \text { to } n \\
& y(t)=\sum_{j=0}^{n} b_{j} t^{j}
\end{aligned}
$$

where $x(t)$ and $y(t)$ are the east-west and north-south positions at the time $t$ with $x$ positive east and $y$ positive north.

The regression coefficients are $a_{j}$ and $b_{j}$. Higher degree polynomials will fit curves with more minimum and maximum values but round off errors become substantial. If a data set is too complex it can be divided up into smaller parts which can be fit with lower order equations. The coefficients were obtained with a polynomial least square regression program for a Hewlett-Packard HP 85 computer. Details of the regression are outlined in Appendix A.

The drogue velocity is obtained by differentiating the polynomial for position, giving :

$$
\begin{aligned}
& u(t)=\sum_{j=1}^{n} j a_{j} t^{j-1}, \text { where } j=1 \text { to } n \\
& v(t)=\sum_{j=1}^{n} j b_{j} t^{j-1}
\end{aligned}
$$

The position of the center of the group of drogues, or centroid, at time $t$ is defined by :

$$
x(t)=1 / k \sum_{i=1}^{k} x_{i}(t) \text { and } y(t)=1 / k \sum_{i=1}^{k} y_{i}(t)
$$

Where drogues are numbered from $i=1$ through $k$.

The velocities of the centroid at time $t$ are :

$$
u(t)=1 / k \sum_{i=1}^{k} u_{i}(t) \text { and } v(t)=1 / k \sum_{i=1}^{k} v_{i}(t)
$$

These parameters can be obtained with two drogues. With three drogues the vorticity, divergence, and deformation rates and a diffusion coefficient can be estimated but accurate estimates of these properties require six or more drogues (Appendix B). 


\section{RESULTS}

Three drogues were followed across the sill on the ebb and flood tides in June 1983. The drogues moved down along the middle of the sill channel on both tides. After passing through the channel they dispersed into the wider regions of the inner bay on the flood tide and outer bay on the ebb tide (Fig. 2). The speed of the centroid was largest across the narrow part of the sill and slowed down with the widening of the channel. The diffusion coefficient across the averaged over both ebb and flood tides is $K=0.65 \times 10^{3} \mathrm{~cm}^{2}$ per second.
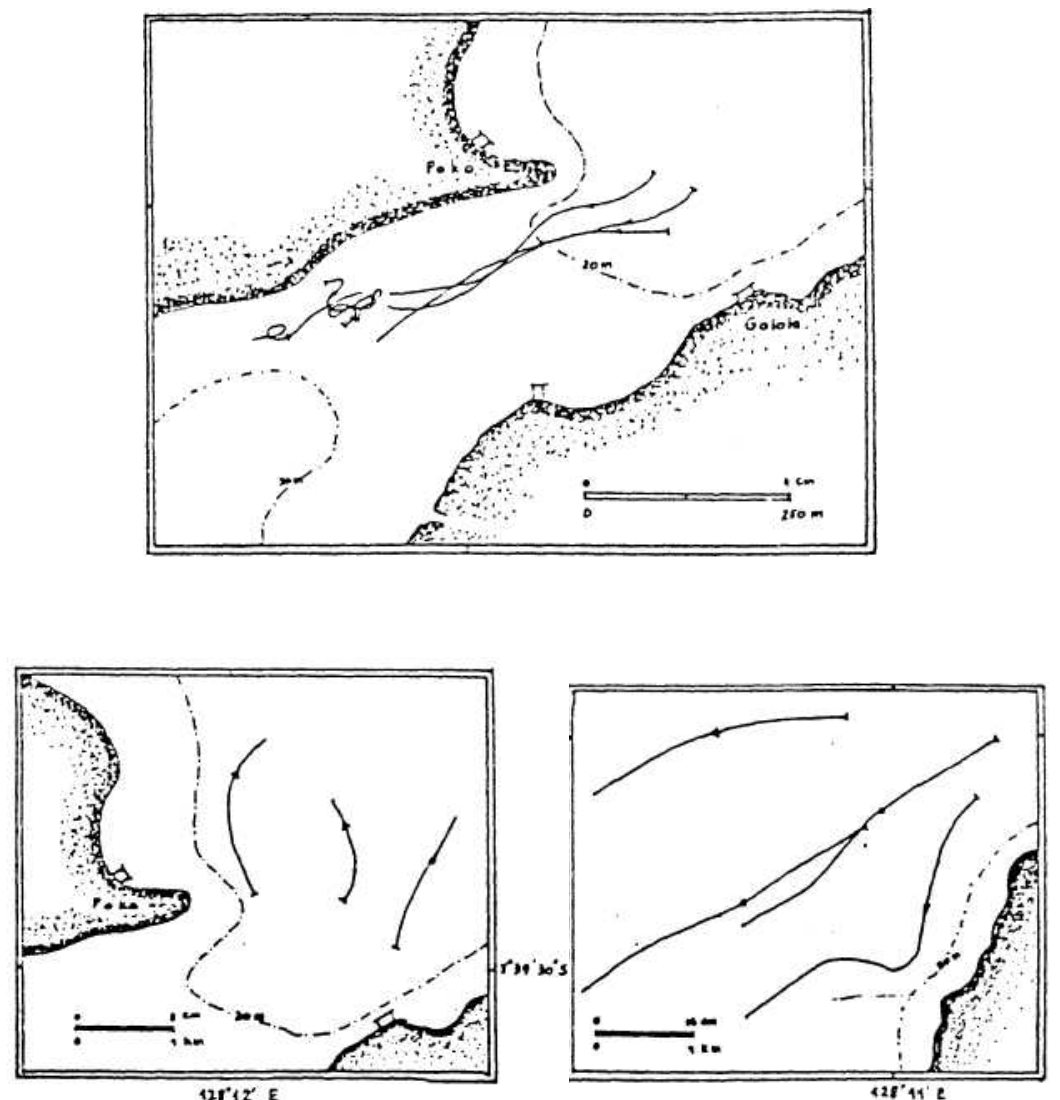

Figure 2. The trajectories of the drogues on the sill (above), inner bay (left) and outer bay (right). 


\section{CURRENTS AND MIXING ON THE SILL OF AMBON BAY}

On the flood tide a narrow counter flow moving against the tide with a variable speed up to $\mathrm{lm} / \mathrm{sec}$ was observed within $10 \mathrm{~m}$ of the beach on northern side of the channel.

In August 1982 three drogues were followed while a strong wind blew from the outer bay towards the inner bay. On the flood tide the wind and the tidal current were in the same direction and the drogues moved quickly across the sill from the outer to the inner bay. On the ebb tide the tidal current opposed the wind and a local down welling formed at the inner edge of the sill where the bottom contours begin to drop sharply towards the inner bay. In this area the drogues and other floatable material were collected.

\section{DISPERSION ON THE SILL}

If a pollutant is released on the sill it will dissipate by advection with the tidal stream and diffusion by tidal mixing. To estimate the advection of a pollutant, it is assumed that a patch of material will move in the same manner as the centroid of the drogues. The residence time of a patch on the sill would be on the order of one hour during the maximum tidal,flow and the total excursion over a tidal cycle is $60 \mathrm{~m}$. If strong winds were blowing along the channel and into the inner bay then material could collect at the inner edge of the sill during the ebb tide. On the following flood tide the material would move into the inner bay.

To estimate the rate of diffusion of a patch we use a radial horizontal mixing equation :

$$
\mathrm{dC} / \mathrm{dt}=(1 / \mathrm{r}) \mathrm{d}(\mathrm{rK} \mathrm{dC} / \mathrm{dr}) / \mathrm{dr}
$$

where $r$ is the distance from the center of the patch to some point, $t$ is time, $C$ is the concentration of the pollutant and $K$ is the horizontal diffusion coefficient.

If a quantity $M$ of a pollutant is released at $t=0$, the spread of the patch can be modeled with the solution of eq. (5) as:

$$
C(r, t)=(M / 4 \pi h K t) \exp \left(-r^{2} / 4 K t\right)
$$

where $h$ is the depth to which the pollutant mixes vertically and $K$ is assumed to be constant.

The size of the patch is described by the horizontal variance which increases with time according to the relation :

$$
s^{2}=4 \mathrm{Kt}
$$

The maximum concentration is at the center of the patch $(\mathrm{r}=0)$ and this decreases with time according to the relation:

$$
\mathrm{C}_{\max }(\mathrm{t})=\mathrm{M} /(4 \pi \mathrm{hKt})
$$




\section{WALMAN \& JJ. Anderson}

The choice of $K$ depends on the scale of the patch. The $K$ determined from the drogue studies is of the appropriate scale for the patches of the diameter of the drogue spacing. As an alternatif Kcan be

$$
\mathrm{K}=\mathrm{cL} 1.15
$$

where $c=0.01$ is the scale of the nuxing in $\mathrm{cm}$ ( $L$ is taken to be the width of the sill) and $K$ has unit of $\mathrm{cm} / \mathrm{sec}$. From observations $K$ is $0.65 \times 10 \mathrm{~cm} \wedge / \mathrm{sec}$ and from eq. (9), $\mathrm{K}=2.5 \times 10^{3} \mathrm{~cm}^{2} / \mathrm{sec}$.

This model gives a first order estimate of the rate of mixing of a pollutant. It does not account for effects of winds and will not describe the nuxing and movement of oil spills. It can be applied to discharge of contaminated water that mixes with the surrounding water. To estimate the rate of dispersion, it is assumed that $1000 \mathrm{~kg}$ of material is released on the sill of Ambon Bay. Assuming the theoritical value for $K$ with $\mathrm{L}=$ $500 \mathrm{~m}$ then over one hour the spread of the patch and the maximum concentration are illustrated in Fig. 3. These estimations are approximate. Winds could cause eddies, counter currents and convergence zones that might tends to concentrate the material in bands at the sill edge or along the shore.

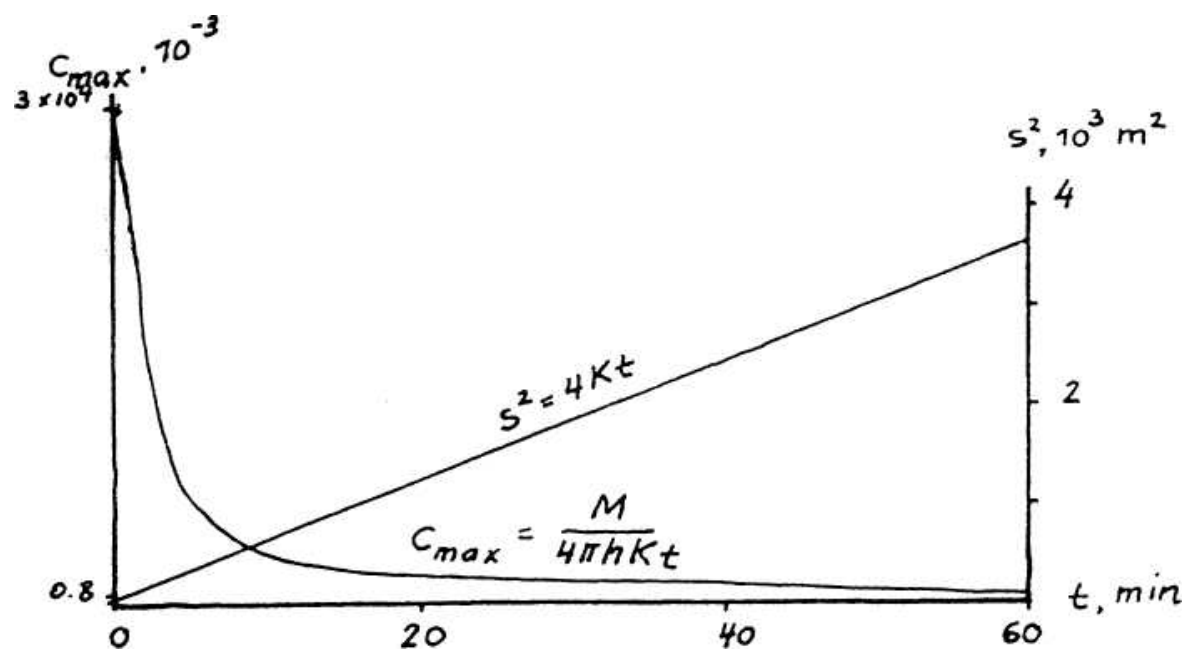

Figure 3. The spread of the patch and the maximum concentration over one hour, $M=1000 \mathrm{~kg}$, and $L=500 \mathrm{~m}$.

\section{ACKNOWLEDGEMENTS}

This work was supported by the U.S. Agency for International Development Contract No. AID-497-79-100 and by LIPI, the Indonesian Institute of Sciences. 


\section{CURRENTS AND MIXING ON THE SILL OF AMBON BAY}

\section{REFERENCES}

ANDERSON, JJ. and D. SAPULETTE 1982. Deep water renewal in inner Ambon Bay, Ambon Indonesia. "Fourth Internat. Coral Reef Symposium" 1 : 369-374.

EBBESMEYER, C.C. and A. OKUBO 1974. A study of current properties and mixing using drogue movements observed near West Point in Puget Sound, Washington. Final report to Municipality of Metropolitan Seattle by Evan-Hamilton Inc. 95 pp.

OKUBO, A 1970. Horizontal dispersion of floatable particles in the vicinity of velocity singularities such as convergences. Deep-Sea Res. $22: 35-40$.

OKUBO, A. 1971. Oceanic diffusion diagrams. Deep-Sea Res. 18 : 789-802.

OKUBO, A. and C.C. EBBESMEYER 1976. Determination of vorticity, divergence, and deformation rates from analysis of drogue observations. Deep—Sea Res. 23 : 349-352.

WENNO, LF. and JJ. ANDERSON 1985. Evidence for tidal upwelling across the sill of Ambon Bay. Afar. Res. Indonesia 23 : 13-20. 


\section{WALMAN \& J.J. ANDERSON}

\section{APPENDIX A}

For the polynomial equation of order $n$

$$
y=b_{0}+b_{1} x+b_{2} x^{2}+b_{3} x^{3}+\ldots \ldots \ldots+b_{n} x^{n}
$$

fit by the methods of least squares, the values of the coefficients $b_{0}, b_{1}, b_{2}, \ldots \ldots ., b_{n}$ are obtained by solving the system equation of $n+1$ linear equations

$$
\begin{aligned}
y & =b_{0}+b_{1} x+b_{2} x^{2}+\ldots \ldots+b_{n} x^{n} \\
x y & =b_{0} x+b_{1} x^{2}+b_{2} x^{2}(x)+\ldots \ldots . .+b_{n} x^{n}(x) \\
x^{n} y & =b_{0} x^{n}+b_{1} x\left(x^{n}\right)+b_{2} x^{2}\left(x^{n}\right)+\ldots \ldots \ldots . .+b_{n} x^{n}\left(x^{n}\right)
\end{aligned}
$$




\section{CURRENTS AND MIXING ON THE SILL OF AMBON BAY}

\section{APENDIX B}

Calculation of the diffusion coefficient from drogue observations according to Окиво and ЕввеSMEYeR (1976). The positions of drogue $i$ at time $t$ are $x_{i}(t)$ and $y_{i}(t)$ and the velocities are $u_{i}(t)$ and $v_{i}(t)$. These are obtained from eq. (1) and eq. (2). The centroid of the group of drogues is defined by

$$
X(t)=\sum_{i=1}^{k} x i(t) / k, \quad y(t)=\sum_{i=1}^{k} y_{i}(t) / k
$$

where $k$ is the number of drogues. The positions of the drogues relative to the centroid are

$$
x^{*}{ }_{i}(t)=X(t)-x_{i}(t), y^{*}{ }_{i}(t)=Y(t)-y_{i}(t)
$$

By matrix representation, the speed of the drogues can be expressed as

$$
\mathrm{U}=\mathrm{RA}+\mathrm{E}
$$

where the following definitions are used :

Position matrices;

$$
\begin{aligned}
& \mathrm{X}(\mathrm{t})=\left|\begin{array}{c}
\mathrm{X}_{1}{ }^{*}(\mathrm{t}) \\
\mathrm{X}_{2}{ }^{*}(\mathrm{t}) \\
\vdots \\
\mathrm{X}_{\mathrm{n}}{ }^{*}(\mathrm{t})
\end{array}\right| \\
& \mathrm{R}(\mathrm{t})=\left|\begin{array}{ccc}
1 & \mathrm{X}_{1}{ }^{*}(\mathrm{t}) & \mathrm{y}_{1}{ }^{*}(\mathrm{t}) \\
1 & \mathrm{X}_{2}{ }^{*}(\mathrm{t}) & \mathrm{y}_{2}{ }^{*}(\mathrm{t}) \\
\vdots & \vdots & \vdots \\
1 & \mathrm{X}_{\mathrm{n}}{ }^{*}(\mathrm{t}) & \mathrm{y}_{\mathrm{n}}{ }^{*}(\mathrm{t})
\end{array}\right|
\end{aligned}
$$

Speed matrices;

$$
\mathrm{U}(\mathrm{t})=\left|\begin{array}{c}
\mathrm{u}_{1}(\mathrm{t}) \\
\mathrm{u}_{2}(\mathrm{t}) \\
\mathrm{u}_{\mathrm{n}}(\mathrm{t})
\end{array}\right| \quad \mathrm{V}(\mathrm{t})=\left|\begin{array}{c}
\mathrm{v}_{1}(\mathrm{t}) \\
\mathrm{v}_{2}(\mathrm{t}) \\
\mathrm{v}_{\mathrm{n}}(\mathrm{t})
\end{array}\right|
$$




\section{WALMAN \& JJ. ANDERSON}

Average current properties matrices;
$A(t)=\left|\begin{array}{c}\bar{u}(t) \\ d \bar{u}(t) / d x \\ d \bar{u}(t) / d y\end{array}\right|$
$B(t)=\left|\begin{array}{c}\bar{v}(t) \\ d \bar{v}(t) / d y \\ d \bar{v}(t) / d x\end{array}\right|$

Turbulence matrices;

$E(t)=\left|\begin{array}{l}u_{1}^{\prime \prime}(t) \\ u_{2}^{\prime \prime}(t) \\ u_{n}^{\prime \prime}(t)\end{array}\right| \quad F(t)=\left|\begin{array}{c}v_{1}{ }^{\prime \prime}(t) \\ v^{\prime \prime}(t) \\ v_{2}^{\prime \prime}(t)\end{array}\right|$

where $u_{i}(t)$ and $v_{i}(t)$ are turbulent speeds at time $t$.

The turbulent matrices are calculated from

$$
\begin{aligned}
& E=\left(1-R\left(R^{\prime} R\right)^{n} R^{\prime}\right) U \\
& F=\left(1-R\left(R^{\prime} R\right)^{\prime \prime} R^{\prime}\right) V
\end{aligned}
$$

where $R^{\prime}$ is the transpose of $R$ and $\left(R^{\prime} R^{\prime \prime}\right)$ is the inverse of $\left(R^{\prime} R\right)$. The horizontal diffusion coefficients are calculated from.

$$
\begin{aligned}
& K_{X}(t)=0.1 \sigma_{u}(t) \sigma_{x}(t) \\
& K_{y}(t)=0.1 \sigma_{v}(t) \sigma_{y}(t)
\end{aligned}
$$

where the standard deviation of the drogue displacements are

$$
\begin{aligned}
& \sigma_{X}(t)=1 /(k-1) \sum_{i=1}^{k} x_{i}(t)-X(t) \\
& \sigma_{y}(t)=1 /(k-1) \sum_{i=1}^{k} y_{i}(t)-Y(t)
\end{aligned}
$$

and the standard deviation of the turbulent speeds are

$$
\begin{aligned}
& \sigma_{u}(t)=1 /(k-1) \sum_{i=1}^{k} u_{i}^{\prime \prime}(t) \\
& \sigma_{v}(t)=1 /(k-1) \sum_{i=1}^{k} v_{i}^{\prime \prime}(t)
\end{aligned}
$$




\section{CURRENTS AND MIXING ON THE SILL OF AMBON BAY}

The horizontal divergence is

$$
\gamma(\mathrm{t})=\mathrm{d} \overline{\mathrm{u}}(\mathrm{t}) / \mathrm{dx}+\mathrm{d} \overline{\mathrm{v}}(\mathrm{t}) / \mathrm{dy}
$$

The relative vorticity is

$$
\eta(t)=d \bar{v}(t) / d x-d \bar{u}(t) / d y
$$

The stretching deformation rate is

$$
\alpha(\mathrm{t})=\mathrm{du}(\mathrm{t}) / \mathrm{dx}-\mathrm{d} \overline{\mathrm{v}}(\mathrm{t}) / \mathrm{dy}
$$

The shearing deformation rate is

$$
\beta(t)=d \bar{v}(t) / d x+d \bar{u}(t) / d y
$$

The presence and type of any velocity singularities are determined according to the graph of $\gamma(t)$ versus $\alpha^{2}(t)+\beta^{2}(t)-\eta^{2}(t)$ and figures given by ОК Uво (1970). 